\title{
Energy values of marine benthic invertebrates from the Canadian Arctic
}

\author{
J. W. Wacasey, E. G. Atkinson \\ Arctic Biological Station, Department of Fisheries and Oceans, 555 St. Pierre Boulevard, Ste-Anne-de-Bellevue, Québec \\ H9X 3R4, Canada
}

\begin{abstract}
Caloric values were determined for 121 species of cold-water benthic invertebrates, 109 of which are representative of a soft bottom community in Frobisher Bay, Northwest Territories (Canada). The mean caloric value for the community was $5.424 \mathrm{kcal} \mathrm{g}^{-1}$ ash-free dry weight ( $\mathrm{SD} \pm 0.403$ ). This is not significantly different from values from lower latitudes, as has been suggested for planktonic communities. With one exception, the Ascidiacea, there were no significant differences in mean caloric value among major taxa. The interspecific distribution of AFDW caloric value is discussed; present data support the growing evidence that the natural pattern is symmetrical with values concentrated about a mean of 5.4 to $5.7 \mathrm{kcal} \mathrm{g}^{-1}$ AFDW for benthic invertebrates. Caloric equivalents for biomass estimates and large-scale community comparisons may be derived from the regression of dry weight caloric value on percent organic content (dry weight): $Y\left(\mathrm{kcal} \mathrm{g}^{-1}\right.$ AFDW $)=-0.3897+0.0605 \mathrm{X}$ ( $\%$ organic content), when the organic fraction is determined directly. Two problematical taxa, Porifera and Echinodermata, are discussed and separate regressions are presented.
\end{abstract}

\section{INTRODUCTION}

Although energy values of many cold-water marine zoobenthic invertebrates are available (Ellis 1960, Brawn et al. 1968, Cummins \& Wuycheck 1971. Tyler 1973, Percy \& Fife 1980, 1981, Bamstedt 1981, Norrbin \& Bamstedt 1984, Steimle \& Terranova 1985), to our knowledge no study has attempted to elucidate the distributional pattern of caloric value in a large number of species accurring in a single natural community in the Arctic.

The use of a variety of methods of expressing biomass estimates (live, whole wet, wet meat, whole dry, dry meat weight) has made comparisons of benthic communities difficult and often misleading. A more suitable expression of standing stock is ash-free dry weight, and caloric equivalents provide basic information for energetic studies.

The present study was undertaken to obtain organic content and caloric equivalents for as many species of benthic invertebrates from Canadian Arctic waters as practicable, and values are presented for 121 species, 114 of which are a representative assemblage from a depth transect in Frobisher Bay. The relevance of the community mean value, taxonomic variations, and interspecific distribution pattern of caloric values is discussed. The relationships between caloric value and organic content gives equations from which fast, reliable estimates of caloric content may be derived from a knowledge of organic content. These may confidently be used for community comparisons where seasonal or intra-specific variation on a variety of parameters is not of primary concern

\section{MATERIALS AND METHODS}

Benthic invertebrates were collected by trawl from stations in the Canadian Arctic during August, between 1968 and 1976. All but 7 species were collected in Frobisher Bay from the intertidal zone to $90 \mathrm{~m}$ depth with 109 species being obtained from soft bottoms at depths between 30 and $65 \mathrm{~m}$. The salinity ( 30 to $34 \%$ ) and temperature $\left(-1.75\right.$ to $0.5^{\circ} \mathrm{C}$ ) of the water immediately above the substrate at the latter range of depths varies little throughout the year.

Specimens were sorted, identified and dried at 60 to $110^{\circ} \mathrm{C}$, usually within $12 \mathrm{~h}$ of capture. Tubes, shells, 
tests and other hard parts were removed where possible, before or after drying. In echinoderms and sponges dry weight includes skeletal material and spicules, because these inorganic structures are difficult to separate mechanically from the organic, and it was considered that acidic decalcification of complex echinoderm skeletons would adversely affect caloric value. Specimens were dried at $100^{\circ} \mathrm{C}$ to constant weight. A detailed discussion of the drying technique is given by Atkinson \& Wacasey (1983). Dried animals were finely pulverized $(0.250 \mathrm{~mm}$, \#60 standard screen) and kept in a desiccator until analysed for ash and caloric content.

A sample consisted of a pool of all individuals of a species collected on a given date. This usually involved a number of animals of variable size, sex and reproductive condition, and believed to be representative of the population of that species in vivo. This study did not attempt to examine seasonal or life-cycle variation in caloric value. Infrequently, a sample consisted of only a single individual; this occurred with some large, widely dispersed species, mostly Asteroidea.

Ashing was carried out in a muffle furnace at a temperature of $500^{\circ} \mathrm{C}$. Ashing time varied from $16 \mathrm{~h}$ in the early determinations to $4 \mathrm{~h}$ in later runs to minimize breakdown of ash (Paine 1966, 1971, Atkinson \& Wacasey 1983). Most samples were ashed in duplicate and a mean was determined from the two values when they differed by less than $1 \%$. The weight loss from ashing is regarded as the organic content, and for convenience, the percent organic content of dry weight (DW) rather than the percent ash weight is presented in Tables 1 \& 2 as this was used to express the caloric content in terms of ash-free dry weight (AFDW).

Homogeneous dry samples were formed into pellets and calorimetric determinations were made with both a Parr model 1243 adiabatic bomb calorimeter with automatic temperature control and the 1107 semi-micro bomb. General calorimetric procedures, as given in Parr manuals 142 (1969) and 144 (1973), and ASTM standards for bomb calorimetry (1971) were followed. Each sample was determined in triplicate and a mean was calculated when the 3 values differed by less than $3 \%$ (Golley 1961).

Corrections for fuse wire and heat of formation of acid were determined and applied to all calculations. In samples with an organic content less than $25 \%$, known amounts of benzoic acid (up to $30 \%$ ) were added to promote ignition and ensure complete burning. Additional corrections were made on samples with large amounts of calcareous (echinoderms) and silicious (sponges) material. Correction factors for water of hydration and endothermic dissociation of $\mathrm{CaCO}_{3}$ were used to adjust ash and caloric values for some species (Table 1). The effects of these correction factors are discussed in greater detail by Atkinson \& Wacasey $(1976,1983)$

\section{RESULTS}

The organic content and energy values determined for 121 species of benthic invertebrates are presented in Table 1, and summarized for major taxa in Table 2. The organic content and caloric values represent the mean of all available sample values (each the mean respectively of duplicate or triplicate determinations) for a given species. Column ' $n$ ' lists the number of such values. Where $n=1$ the percent organic content range is $1 \%$; caloric value $\mathrm{SD}$ and confidence interval are derived from the 3 replicates; where $n>1, S D$ and confidence interval are derived from the total number of sample values summed. Thus the $95 \%$ confidence limits of the caloric values are large when few and significantly different sample values are combined.

The grand mean of AFDW caloric values was $5.424 \mathrm{kcal} \mathrm{g}^{-1}$ ( $\left.\mathrm{SD} \pm 0.403\right)$. The distribution of values (Fig.1) was negatively skewed $\left(g_{1}=-1.115\right)$ and leptokurtic $\left(g_{2}=2.447\right)$.

The regression of AFDW caloric value on percent organic content for the values presented in Table 1 , is $\mathrm{Y}$ $\left(\mathrm{kcal} \mathrm{g} \mathrm{g}^{-1}\right.$ AFDW $)=0.0149 \mathrm{X}(\%$ organic content $)+$ $4.396(r=0.568, \mathrm{~d} f=180, \mathrm{t}=9.26, \mathrm{p}<0.001)$. This excludes data from Echinodermata and Porifera which have a high ash content due to inclusion of inorganic skeletal material, and which have had caloric estimates corrected for water of hydration and endothermy.

A summary of regressions of caloric value per unit DW on percent organic content for major taxa, and all individual samples is presented in Table 3 and Fig. 2. These regressions represent caloric value as determined in the bomb, with no correction applied for endothermy, and organic content obtained from muffle furnace combustion, with no correction applied for water of hydration. The Echinodermata include only those species from which the skeleton could not be removed. The regressions for Echinodermata and Porifera based on corrected data in Table 3 and depicted in Fig. 3 demonstrate the effect of compensating for inaccuracies which are known to arise, and will be discussed below. The regression equation for all data was $Y\left(\mathrm{kcal} \mathrm{g}^{-1} \mathrm{DW}\right)=-0.3897+0.0605 X(\%$ organic content; $r=0.986, \mathrm{df}=211, \mathrm{t}=87.114, \mathrm{p}<0.001$ ). This may be used to predict accurate caloric values when organic content has been determined directly, except for the Echinodermata and Porifera. For these taxa, adjustments for water of hydration and endothermy have been made to give more accurate predictive equations. For Porifera this was $\mathrm{Y}=-0.3141+$ $0.0588 \mathrm{X}$; for Echinodermata, $\mathrm{Y}=-0.4037+0.0617 \mathrm{X}$. 
Table 1. Organic content and caloric values of marine benthic invertebrates from the Canadian Arctic

\begin{tabular}{|c|c|c|c|c|c|c|c|}
\hline Species & $\mathrm{n}$ & $\begin{array}{c}\text { Organic } \\
\% \text { DW }\end{array}$ & Range & $\begin{array}{c}\mathrm{kcal} \mathrm{g}^{-1} \\
\mathrm{DW}\end{array}$ & $\begin{array}{l}\mathrm{kcal} \mathrm{g}^{-1} \\
\text { AFDW }\end{array}$ & $\pm S D$ & $\begin{array}{c} \pm 95 \% \\
\mathrm{CI}\end{array}$ \\
\hline \multicolumn{8}{|l|}{ ANNELIDA: Polychaeta } \\
\hline Amphitrite groenlandica & 1 & 71.1 & - & 4.107 & 5.777 & 0.011 & 0.034 \\
\hline Branchiomma infarcta & 1 & 80.6 & - & 4.477 & 5.554 & 0.049 & 0.151 \\
\hline Enipo gracilis & 2 & 68.3 & $60.3-76.3$ & 3.653 & 5.350 & 0.034 & 0.047 \\
\hline Harmothoe nodosa & 1 & 73.4 & - & 4.036 & 5.499 & 0.010 & 0.131 \\
\hline Harmothoe oerstedi & 2 & 80.2 & $77.5-82.8$ & 4.314 & 5.382 & 0.013 & 0.161 \\
\hline Lumbrineris fragilis & 1 & 88.4 & - & 5.035 & 5.696 & 0.012 & 0.036 \\
\hline Myriochele heeri & 1 & - & - & 1.079 & 5.422 & 0.046 & 0.139 \\
\hline Nephtys ciliata & 1 & 72.9 & - & 3.982 & 5.462 & 0.054 & 0.164 \\
\hline Nephtys paradoxa & 1 & 84.4 & - & 5.131 & 6.079 & 0.067 & 0.204 \\
\hline Nicomache lumbricalis & 3 & 66.9 & $62.9-69.0$ & 3.590 & 5.371 & 0.015 & 0.446 \\
\hline Pherusa plumosa & 1 & 42.7 & - & 2.263 & 5.299 & 0.034 & 0.428 \\
\hline Phyllodoce groenlandica & 1 & 71.6 & - & 4.010 & 5.601 & 0.079 & 1.009 \\
\hline Pista flexuosa & 1 & 58.6 & - & 3.382 & 5.771 & 0.011 & 0.136 \\
\hline Pista maculata & 1 & 78.2 & - & 4.740 & 6.061 & 0.017 & 0.051 \\
\hline Praxillella praetermissa & 1 & 76.2 & - & 4.171 & 5.474 & 0.062 & 0.188 \\
\hline Sabella crassicornis & 1 & 82.4 & - & 4.629 & 5.618 & 0.019 & 0.059 \\
\hline Scalibregma inflatum & 1 & 43.3 & - & 2.186 & 5.048 & - & - \\
\hline Thelepus cincinnatus & 2 & 79.4 & $71.6-87.2$ & 4.487 & 5.627 & 0.336 & 4.277 \\
\hline \multicolumn{8}{|l|}{ ARTHROPODA : Amphipoda } \\
\hline Anonys nugax & 2 & 66.1 & $65.0-67.2$ & 3.960 & 5.990 & 0.049 & 0.629 \\
\hline Gammarus oceanicus/setosus & 1 & 65.2 & - & 3.610 & 5.537 & 0.010 & 0.032 \\
\hline Paramphithoe hystrix & 1 & 55.9 & - & 3.076 & 5.502 & 0.031 & 0.095 \\
\hline Stegocephalus inflatus & 2 & 61.5 & $57.8-65.2$ & 3.737 & 6.106 & 0.678 & 8.616 \\
\hline \multicolumn{8}{|l|}{ ARTHROPODA: Cirripedia } \\
\hline Balanus balanoides & 1 & 79.7 & - & 4.552 & 5.712 & 0.050 & 0.153 \\
\hline Balanus balanus & 3 & 70.0 & $66.9-72.8$ & 3.772 & 5.387 & 0.059 & 0.178 \\
\hline Balanus crenatus & 1 & 67.3 & - & 3.656 & 5.432 & 0.048 & 0.145 \\
\hline \multicolumn{8}{|l|}{ ARTHROPODA : Cumacea } \\
\hline Diastylis goodsiri & 1 & 43.7 & - & 1.991 & 4.557 & 0.028 & 0.086 \\
\hline \multicolumn{8}{|l|}{ ARTHROPODA : Decapoda } \\
\hline Argis dentata & 3 & 77.3 & $73.4-79.6$ & 4.402 & 5.684 & 0.359 & 1.091 \\
\hline Eualus gaimardi & 1 & 62.3 & - & 3.301 & 5.298 & 0.025 & 0.077 \\
\hline Lebbeus groenlandicus & 4 & 69.8 & $62.3-75.6$ & 3.961 & 5.668 & 0.194 & 0.357 \\
\hline Pagurus pubescens & 1 & 53.6 & - & 3.033 & 5.659 & 0.040 & 0.122 \\
\hline Sabinea septemcarinata & 2 & 79.7 & 0.0 & 4.397 & 5.517 & 0.117 & 1.491 \\
\hline Sclerocrangon boreas & 6 & 753 & $67.1-79.6$ & 4.241 & 5.633 & 0.174 & 0.200 \\
\hline Spirontocaris spinus & 7 & 69.0 & $62.8-74.1$ & 3.867 & 5.608 & 0.101 & 0.101 \\
\hline \multicolumn{8}{|l|}{ ARTHROPODA : Isopoda } \\
\hline Arcturus baffini & 5 & 49.5 & $46.1-53.0$ & 2.478 & 5.012 & 0.702 & 0.975 \\
\hline Mesidotea entomon ${ }^{1}$ & 1 & 58.2 & - & 3.388 & 5.821 & 0.014 & 0.042 \\
\hline Mesidotea sabini ${ }^{1}$ & 1 & 58.3 & - & 3.425 & 5.875 & 0.015 & 0.046 \\
\hline \multicolumn{8}{|l|}{ ARTHROPODA : Pycnogonida } \\
\hline Nymphon hirtipes & 3 & 48.3 & $31.3-68.1$ & 2.506 & 5.137 & 0.206 & 0.626 \\
\hline \multicolumn{8}{|l|}{ BRACHIOPODA } \\
\hline Hemithyris psittacea & 3 & 57.4 & $50.7-64.8$ & 3.002 & 5.242 & 0.312 & 0.950 \\
\hline \multicolumn{8}{|l|}{ CHORDATA:Ascidiacea } \\
\hline Ascidia callosa & 2 & 32.7 & $25.4-40.0$ & 1.511 & 4.533 & 0.559 & 7.098 \\
\hline Boltenia echinata & 1 & 11.9 & - & 0.584 & 4.908 & 0.139 & 0.423 \\
\hline Boltenia ovifera & 3 & 45.4 & $32.1-46.8$ & 2.300 & 4.968 & 0.335 & 0.616 \\
\hline Ciona intestinalis & 2 & 25.8 & $22.4-29.1$ & 0.981 & 3.803 & 0.073 & 0.925 \\
\hline Dendrodoa aggregata & 1 & 52.3 & - & 2.629 & 5.026 & 0.070 & 0.213 \\
\hline Kukenthalia borealis & 1 & 35.9 & - & 1.650 & 4.595 & 0.086 & 0.260 \\
\hline Pelonaia corrugata & 1 & 42.0 & - & 1.954 & 4.653 & 0.052 & 0.159 \\
\hline Rhizomolgula globularis ${ }^{1}$ & 1 & 37.0 & - & 1.704 & 4.605 & 0.020 & 0.062 \\
\hline Styela rustica & 2 & 27.3 & $21.7-32.8$ & 1.300 & 4.695 & 0.518 & 6.582 \\
\hline
\end{tabular}


Table 1 (continued)

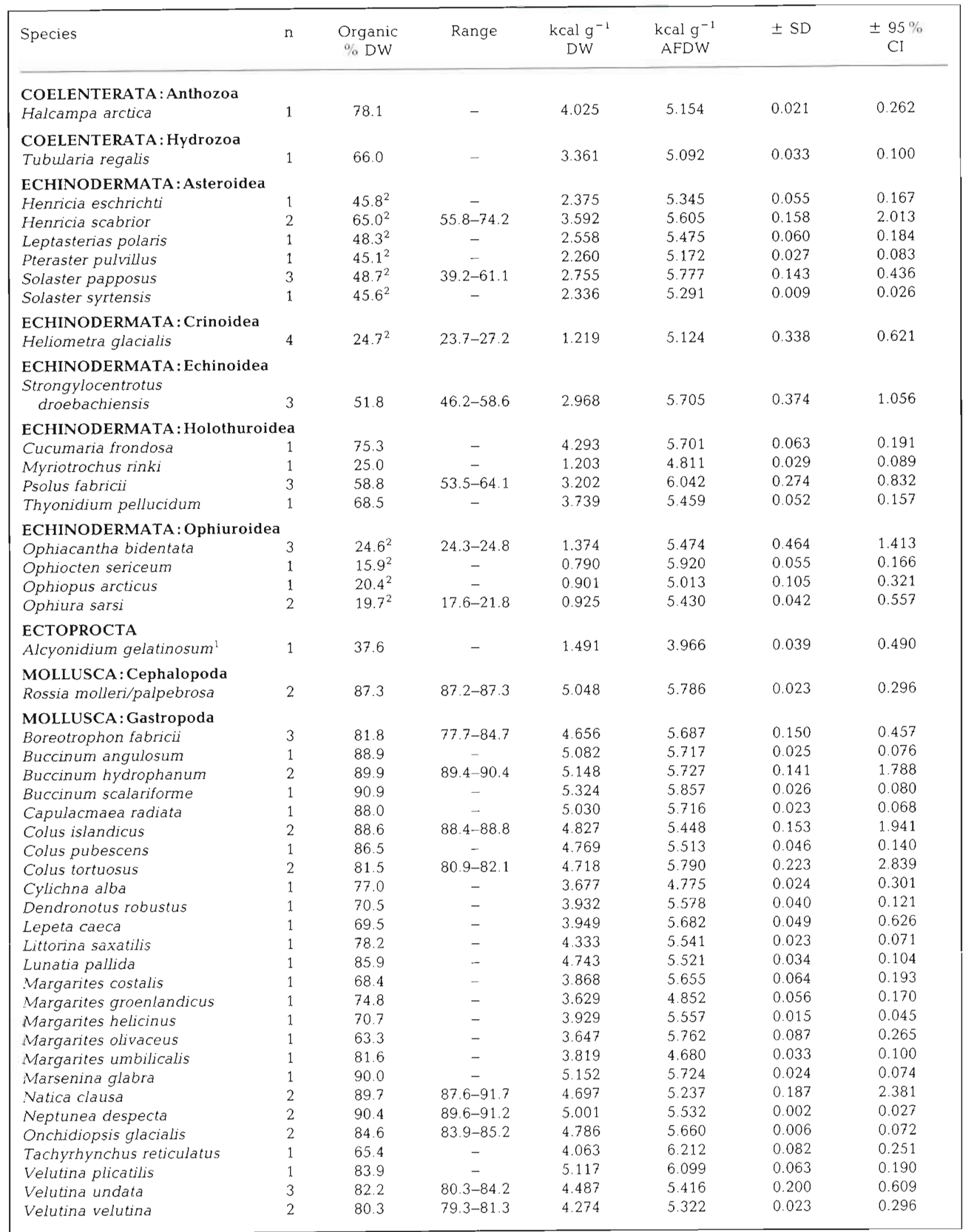


Table 1 (continued)

\begin{tabular}{|c|c|c|c|c|c|c|c|}
\hline Species & $\mathrm{n}$ & $\begin{array}{l}\text { Organic } \\
\% \text { DW }\end{array}$ & Range & $\begin{array}{c}\mathrm{kcal} \mathrm{g}^{-1} \\
\mathrm{DW}\end{array}$ & $\begin{array}{l}\mathrm{kcal} \mathrm{g}^{-1} \\
\text { AFDW }\end{array}$ & $\pm \mathrm{SD}$ & $\begin{array}{c} \pm 95 \% \\
\mathrm{Cl}\end{array}$ \\
\hline \multicolumn{8}{|l|}{ MOLLUSCA: Pelecypoda } \\
\hline Astarte borealis & 3 & 83.6 & $81.3-87.5$ & 4.486 & 5.370 & 0.254 & 0.774 \\
\hline Astarte montagui & 1 & 78.5 & - & 4.120 & 5.248 & 0.002 & 0.025 \\
\hline Chlamys islandica & 2 & 87.0 & $86.8-87.2$ & 4.634 & 5.273 & 0.204 & 2.597 \\
\hline Clinocardium ciliatum & 4 & 83.6 & $78.6-86.2$ & 4.539 & 5.431 & 0.177 & 0.325 \\
\hline Hiatella arctica & 4 & 74.9 & $72.8-77.3$ & 3.956 & 5.283 & 0.231 & 0.424 \\
\hline Macoma calcarea & 2 & 78.8 & $77.3-80.3$ & 4.293 & 5.446 & 0.150 & 1.905 \\
\hline Macoma moesta & 2 & 76.7 & $76.3-77.1$ & 4.147 & 5.406 & 0.048 & 0.611 \\
\hline Musculus discors & 4 & 81.8 & $80.1-82.9$ & 4.595 & 5.616 & 0.073 & 0.134 \\
\hline Musculus niger & 3 & 83.5 & $77.1-87.3$ & 4.624 & 5.538 & 0.016 & 0.049 \\
\hline Mya truncata & 3 & 64.3 & $61.8-67.7$ & 3.317 & 5.161 & 0.110 & 0.336 \\
\hline Mytilus edulis ${ }^{2}$ & 2 & 86.4 & $86.3-86.5$ & 4.893 & 5.664 & 0.035 & 0.440 \\
\hline Nucula belloti & 1 & 81.0 & - & 4.766 & 5.884 & 0.011 & 0.035 \\
\hline Nuculana minuta & 2 & 71.4 & $69.4-73.4$ & 3.909 & 5.476 & 0.065 & 0.827 \\
\hline Nuculana pernula & 2 & 73.3 & $71.1-75.4$ & 4.019 & 5.487 & 0.047 & 0.593 \\
\hline Pandora glacialis & 1 & 78.4 & - & 4.016 & 5.123 & 0.064 & 0.194 \\
\hline Pecten groenlandicus & 1 & 50.5 & - & 2.780 & 5.505 & 0.037 & 0.112 \\
\hline Periploma abyssorum & 1 & 49.5 & - & 2.612 & 5.276 & 0.050 & 0.637 \\
\hline Portlandia intermedia ${ }^{1}$ & 3 & 82.4 & $78.9-87.3$ & 5.133 & 6.219 & 0.319 & 0.971 \\
\hline Serripes groenlandicus & 2 & 81.1 & $77.4-84.8$ & 4.503 & 5.558 & 0.201 & 2.552 \\
\hline Thyasira gouldi & 1 & 78.5 & - & 4.177 & 5.321 & 0.005 & 0.014 \\
\hline Yoldia hyperborea & 1 & 80.0 & - & 4.323 & 5.404 & 0.019 & 0.059 \\
\hline \multicolumn{8}{|l|}{ NEMERTINA } \\
\hline Nemerteans & 1 & 80.1 & - & 4.265 & 5.325 & 0.011 & 0.035 \\
\hline \multicolumn{8}{|l|}{ PORIFERA } \\
\hline Haliclona gracilis & 2 & $26.2^{2}$ & $18.2-34.2$ & 1.409 & 5.262 & 0.519 & 6.595 \\
\hline Lissodendoryx indistincta & 1 & $26.0^{2}$ & - & 1.421 & 5.477 & 0.012 & 0.036 \\
\hline Mycale lingua & 2 & $26.6^{2}$ & $23.7-29.5$ & 1.446 & 5.447 & 0.062 & 0.791 \\
\hline Polymastia mammillaris & 2 & $27.4^{2}$ & $24.9-29.8$ & 1.470 & 5.378 & 0.076 & 0.961 \\
\hline Tetilla sibirica & 1 & $18.1^{2}$ & - & 1.007 & 5.541 & 0.013 & 0.038 \\
\hline \multicolumn{8}{|l|}{ SIPUNCULA } \\
\hline Golfingia margaritacea & 1 & 58.0 & - & 3.113 & 5.367 & 0.076 & 0.231 \\
\hline
\end{tabular}

Table 2. Mean organic content and caloric values of taxa represented by more than 2 species

\begin{tabular}{|lrcccccc|}
\hline Taxon & $\begin{array}{c}\text { No. } \\
\text { of species }\end{array}$ & $\begin{array}{c}\text { Mean org. } \\
\text { content \% DW }\end{array}$ & Range & $\begin{array}{c}\text { Mean kcal } \\
\mathrm{g}^{-1} \mathrm{DW}\end{array}$ & $\begin{array}{c}\text { Mean kcal } \\
\mathrm{g}^{-1} \text { AFDW }\end{array}$ & \pm SD & $\pm 95 \% \mathrm{CI}$ \\
\hline Polychaeta & 18 & 71.7 & $42.7-88.4$ & 3.848 & 5.561 & 0.257 & 0.131 \\
Amphipoda & 4 & 62.2 & $55.9-67.2$ & 3.596 & 5.784 & 0.309 & 0.568 \\
Cirripedia & 3 & 72.3 & $66.9-79.7$ & 3.993 & 5.510 & 0.176 & 0.536 \\
Decapoda & 7 & 69.6 & $53.6-79.7$ & 3.886 & 5.581 & 0.137 & 0.136 \\
Isopoda & 3 & 55.3 & $46.1-53.0$ & 3.097 & 5.569 & 0.483 & 1.471 \\
Ascidiacea & 9 & 34.5 & $11.9-52.3$ & 1.624 & 4.648 & 0.362 & 0.294 \\
Asteroidea & 6 & 49.8 & $39.2-74.2$ & 2.646 & 5.444 & 0.221 & 0.254 \\
Holothuroidea & 4 & 56.9 & $25.0-75.3$ & 3.109 & 5.503 & 0.520 & 0.955 \\
Ophiuroidea & 4 & 20.2 & $15.9-24.8$ & 0.997 & 5.459 & 0.371 & 0.681 \\
Gastropoda & 26 & 80.9 & $63.3-91.7$ & 4.487 & 5.548 & 0.354 & 0.146 \\
Pelecypoda & 21 & 76.4 & $49.5-87.5$ & 4.183 & 5.461 & 0.247 & 0.115 \\
Porifera & 5 & 24.9 & $18.1-34.2$ & 1.351 & 5.421 & 0.106 & 0.148 \\
\hline
\end{tabular}




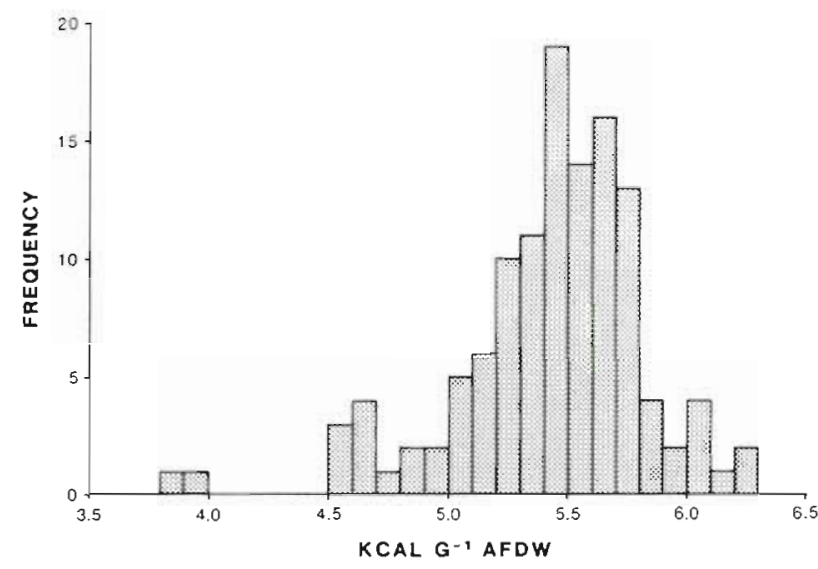

Fig. 1. Frequency distribution of caloric values for 121 benthic invertebrates

\section{DISCUSSION}

Examination of AFDW caloric values in Table 2 reveals that with the exception of the Ascidiacea, none of the taxa differ significantly from each other. Prus (1970) demonstrated that caloric values within taxonomic groups are symmetrically distributed about a mean that is similar for most groups. This probably reflects a variety of feeding types within most higher taxa which would tend to minimize caloric differences at this level and casts doubt on the validity of treating members of a taxon as energetic equivalents in general community comparisons. The Ascidiacea, all filter feeders, are thought to have a low caloric value due to high ash content, a relationship to be discussed presently. The grand mean for all species, $5.424 \mathrm{kcal} \mathrm{g}^{-1}$ AFDW, is similar to the value for proteinaceous material $(5.7 \mathrm{kcal})$ and agrees with $5.470 \mathrm{kcal} \mathrm{g}^{-1}$ AFDW for aquatic invertebrates (Cummins \& Wuycheck 1971) and with 5.429

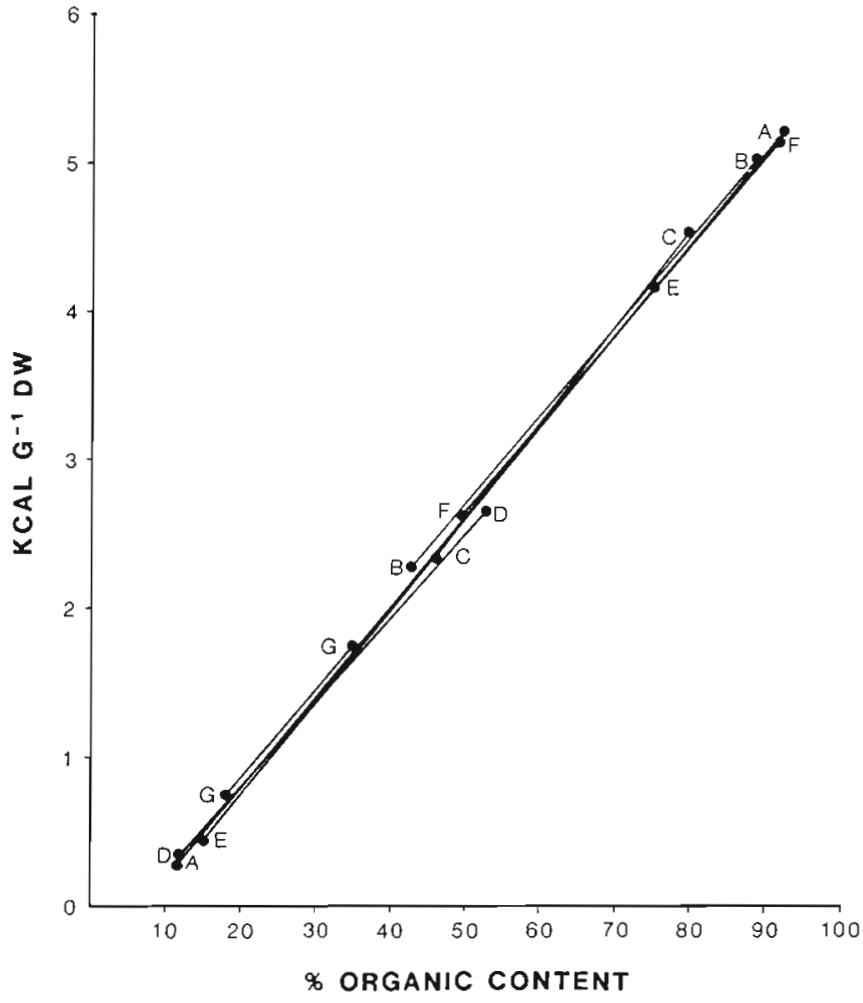

Fig. 2. Regression of DW caloric value on percent organic content. A: all values; B: Polychaeta; C: Crustacea; D: Ascidiacea; E: Echinodermata (with skeleton); F: Mollusca; G: Porifera

$\mathrm{kcal} \mathrm{g}^{-1}$ AFDW calculated from the invertebrate values of Thayer et al. (1973). It is slightly lower than community means (5.6 to $5.7 \mathrm{kcal} \mathrm{g}^{-1}$ AFDW) determined by other investigators (Ostapenya \& Sergeev 1963, Paine 1964, Griffiths 1977, Norrbin \& Bamstedt 1984).

Griffiths (1977) postulated that in response to

Table 3. Regression of dry weight caloric value on percent organic content for major taxa

\begin{tabular}{|c|c|c|c|c|c|c|c|c|}
\hline Taxon & $\begin{array}{c}\% \text { Org. content } \\
\text { interval }\end{array}$ & n & $\begin{array}{c}y \\
\text { intercept }\end{array}$ & $\begin{array}{l}\text { Regression } \\
\text { slope }\end{array}$ & $\mathrm{r}$ & $t$ & $t_{0.05}$ & Probability \\
\hline Polychaeta & $42.7-88.4$ & 23 & -02693 & 0.0595 & 0.985 & 26.557 & 2.080 & $p<0.001$ \\
\hline Crustacea & $46.1-79.7$ & 43 & -0.5766 & 0.0644 & 0.952 & 20.919 & 2.021 & $p<0.001$ \\
\hline Ascidiacea & $11.9-52.3$ & 15 & -0.3454 & 0.0573 & 0.990 & 25.559 & 2.160 & $p<0.001$ \\
\hline Echinodermata ${ }^{1}$ & $15.9-74.2$ & 21 & -0.4794 & 0.0619 & 0.994 & 39.851 & 2.093 & $p<0.001$ \\
\hline Echinodermata ${ }^{2}$ & $15.9-74.2$ & 21 & -0.1204 & 0.0584 & 0.993 & 36.904 & 2.093 & $p<0.001$ \\
\hline Mollusca & $49.5-91.7$ & 84 & -0.3698 & 0.0598 & 0.904 & 21.181 & 1.993 & $\mathrm{p}<0.001$ \\
\hline Porifera ${ }^{3}$ & $18.1-34.2$ & 8 & -0.3141 & 0.0588 & 0.980 & 12.309 & 2.365 & $p<0.001$ \\
\hline Porifera ${ }^{4}$ & $18.1-34.2$ & 8 & -0.1088 & 0.0585 & 0.992 & 19.404 & 2.365 & $p<0.001$ \\
\hline All values ${ }^{5}$ & $11.9-91.7$ & 213 & -0.3897 & 0.0605 & 0.986 & 87.114 & 1.960 & $p<0.001$ \\
\hline \multicolumn{9}{|c|}{$\begin{array}{l}{ }^{1} \text { With skeleton. Organic content uncorrected for wate } \\
{ }^{2} \text { With skeleton. Appropriate corrections applied to or } \\
{ }^{3} \text { Organic content uncorrected for water of hydration } \\
{ }^{4} \text { Organic content corrected for water of hydration } \\
5 \text { Uncorrected for water of hydration or endothermy }\end{array}$} \\
\hline
\end{tabular}


decreasing environmental predictability with increasing latitude, organisms should tend to store increasing amounts of energy and have higher caloric values. Bamstedt (1981) summarized some data on lipid and energy content of several zooplankton species which support this hypothesis. It is unclear, however, to what extent the data are seasonal, or what proportion of a community is represented. The mean value for the Frobisher Bay benthic community, when compared with those from lower latitudes, does not support this premise. Since samples for this study were collected in August at the time of peak reproductive activity in arctic waters, the mean is likely near the high end of the range of annual variation; however, it is at the low end of the range of estimates discussed above. Other studies reported by Clarke (1983) indicate no increase in lipid storage with increasing latitude in benthic invertebrates.

Frequency distributions of AFDW caloric value have been presented and discussed by various investigators (Slobodkin \& Richman 1961, Prus 1970, Cummins \& Wuycheck 1971, Thayer et al. 1973, Norrbin \& Bamstedt 1984). Although not always representative of natural communities, the available data strongly indicate a natural pattern symmetrical about a mean in the range of 5.4 to $5.7 \mathrm{kcal} \mathrm{g}^{-1}$ AFDW. Most values in a community are grouped close to this, reflecting an optimal and consistent biochemical composition. According to Slobodkin \& Richman (1961) this pattern implies a selection against caloric values that deviate in either direction from the mean. The slight negative skewness of the distribution presented in Fig. 1 is attributable to a lack of representative fish values. If the observed leptokurtosis is not a similar artifact, it further supports the idea of selection toward an optimal biochemical composition which is reflected in the caloric value.

The relationship reported above between AFDW caloric value and percent organic content $(Y=0.0149 X$ +4.396 ) is similar to the one obtained by Thayer et al. (1973) for estuarine benthic invertebrates near Beaufort, North Carolina (USA), which took the form $\mathrm{K}$ (kcal g $\mathrm{g}^{-1}$ AFDW) $=0.0183 \times$ ( $\%$ organic content $)$ +3.991 . The relationship shown in this study, as with Thayer's, is significant but not particularly strong. The implication is that increasing ash content is associated with organic material of decreasing caloric value, assuming there is no systematic effect of ash on caloric value as determined in bomb calorimeters. Although this was not noted in the present research, it is reasonable to suspect any value for animal material below $4.2 \mathrm{kcal} \mathrm{g}^{-1}$ AFDW (the value for carbohydrate). This includes the values reported in Table 1 for the ascidian Ciona intestinalis and the ectoproct Alcyonidium gelatinosum.
The positive correlation between organic content and caloric value per unit DW has been discussed by a number of authors (Ostapenya \& Sergeev 1963, Platt et al. 1969, Prus 1970, Thayer et al. 1973, Norrbin \& Bamstedt 1984). The differences among the regressions presented by these authors and that reported here are slight. However, the variation between taxa in both slope and intercept value (Table 3, Fig. 2) is much less in the present study than reported by Norrbin $\&$ Bamstedt (1984) for their benthic data. This can be accounted for mainly by larger sample size for all taxa in this study.

Ostapenya \& Sergeev (1963) demonstrated that regressions of DW caloric value on percent organic content more closely approach the origin with increasing accuracy of the caloric determination technique. This was noted in the present work and is depicted in Fig. 3 where the regressions for the Porifera and Echinodermata (Table 3) are compared prior to and following application of appropriate corrections for water of hydration and endothermy. It will be noted

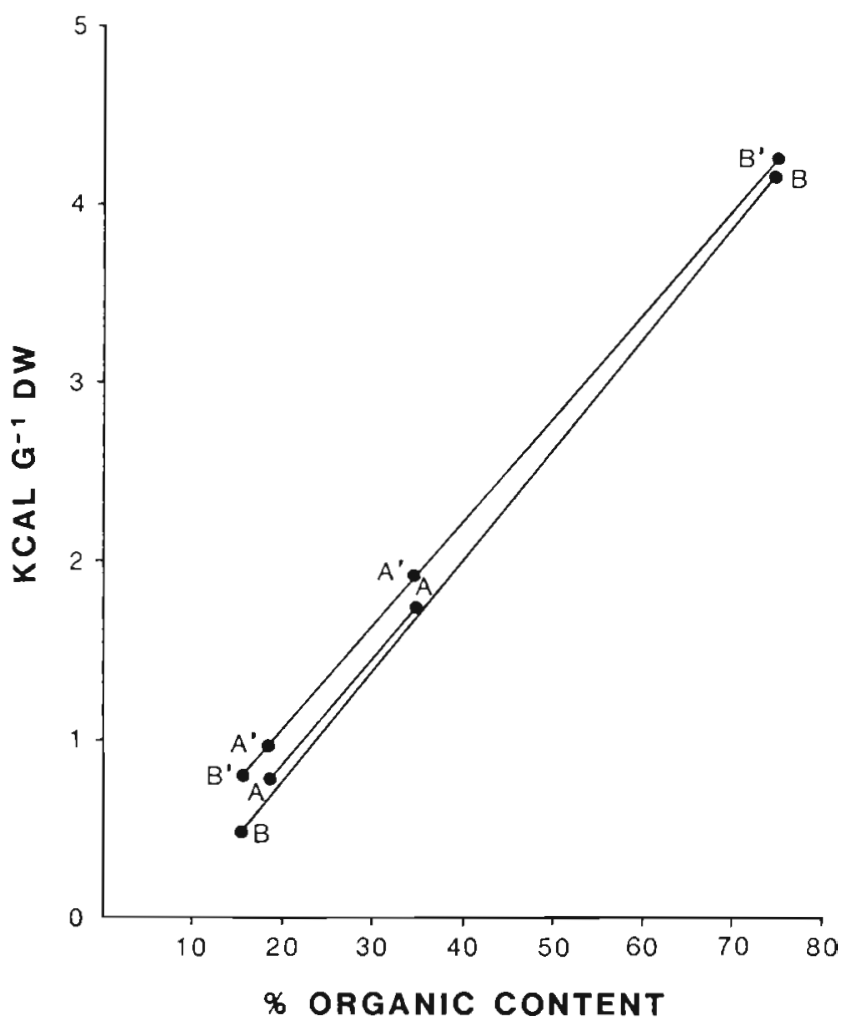

Fig. 3. Regression of DW caloric value on percent organic content. A: Porifera, organic content uncorrected for water of hydration; A': Porifera, organic content corrected for water of hydration. B: Echinodermata (with skeleton), organic content uncorrected for water of hydration, caloric value uncorrected for endothermy; $B^{\prime}$ : Echinodermata (with skeleton), organic content corrected for water of hydration, caloric value corrected for endothermy 
that the regressions for corrected data, $\mathrm{A}^{\prime}-\mathrm{A}^{\prime}$ and $\mathrm{B}^{\prime}-\mathrm{B}^{\prime}$ for Porifera and Echinodermata, respectively, become coincident with a $Y$-intercept value of approximately $-0.11 \mathrm{kcal} \mathrm{g}^{-1} \mathrm{DW}$. Thus these 2 groups, adjusted for errors, have 2 of the highest correlations and their regression lines pass closest to the origin.

Thus a rigorous technique combined with large sample size can yield highly reliable equations to predict caloric value if percent organic content is determined directly. This is highly variable both intra- and interspecifically (Table 1) and is the single most important factor in the calculation, especially if AFDW values are desired. A simpler but less accurate approximation can be obtained by applying mean AFDW caloric values for taxa (Table 2), or a grand mean of invertebrate values which in the case of this study is $5.424 \mathrm{kcal} \mathrm{g}^{-1}$ AFDW.

These techniques are suitable for estimating standing stocks and making large scale comparisons of communities. However, detailed studies of energy partitioning and flow within populations and communities require detailed and accurate determinations of all variables.

Acknowledgements. We thank Dr J. A. Percy and Dr E. H. Grainger, both of the Arctic Biological Station, for valuable suggestions and critical review of the manuscript. Another colleague, Joseph Lovrity, assisted with field collections and preparation of the figures.

\section{LITERATURE CITED}

American Society for Testing Materials (ASTM) (1971). Standards for bomb calorimetry. Authorized reprint from Annual Book of ASTM Standards, Philadelphia

Atkinson, E. G., Wacasey, J. W (1976). Caloric values of zoobenthos and phytobenthos from the Canadian Arctic. Fish. Mar Serv. Res. Dev. Tech. Rep. 632: 1-24

Atkinson, E. G., Wacasey, J. W. (1983). Caloric equivalents for benthic marine organisms from the Canadian Arctic. Can. Tech. Rep. Fish. Aquat. Sci. 1216: 1-31

Bamstedt, U. (1981). Water and organic content of boreal macrozooplankton and their significance for the energy content. Sarsia 66: 59-66

Brawn, V. M., Peer, D. L., Bentley, R. J. (1968). Caloric content of the standing crop of benthic and epibenthic invertebrates of St. Margaret's Bay, Nova Scotia. J. Fish. Res. Bd Can. 25 (9): 1803-1811

Clarke, A. (1983). Life in cold water. In: Barnes, M. (ed.)
Oceanography and marine biology, Vol. 21. Aberdeen Univ. Press, Aberdeen, p. 341-453

Cummins, K. W., Wuycheck, J. C. (1971). Caloric equivalents for investigations in ecological energetics. Mitt. int. Verein. theor. angew. Limnol. 18: 1-158

Ellis, D. V (1960). Marine infaunal benthos in Arctic North America. Arctic Institute of North America, Tech. Paper No. 5

Golley, F. F. (1961). Energy values of ecological materials. Ecology 42 (3): 581-584

Griffiths, D. (1977). Caloric variation in Crustacea and other animals. J. Anim. Ecol. 46: 593-605

Norrbin, F., Bamstedt, U. (1984). Energy contents in benthic and planktonic invertebrates of Kosterfjorden, Sweden. A comparison of energetic strategies in marine organism groups. Ophelia 23 (1): 47-64

Ostapenya, A. P., Sergeev, A. I. (1963). The caloric content of the dry substance of aquatic invertebrates used as food by fish. Vopr. Ikhtiol. 3: 177-183 (Russian; transl. by Fish. Res. Bd Can. Trans. Ser. 874)

Paine, R. T. (1964). Ash and caloric determinations of sponge and opisthobranch tissues. Ecology 45: 384-387

Paine, R. T. (1966). Endothermy in bomb calorimetry, Limnol. Oceanogr. 11: 126-129

Paine, R. T (1971). The measurement and application of the calorie to ecological problems. Ann. Rev. Ecol. Syst 2 . $145-164$

Parr Instrument Company (1969). Instructions for 1241 and 1242 Adiabatic Calorimeters. Manual No. 142. Moline. Illinois

Parr Instrument Company (1973). Instructions for the 1411 Semimicro Oxygen Bomb Calorimeter. Manual No. 144. Moline, Illinois

Percy, J. A., Fife, F. J. (1980). The proximate composition and caloric content of arctic marine invertebrates from Frobisher Bay. Can. Data Rep. Fish. Aquat. Sci. 214: 1-35

Percy, J. A., Fife, F. J. (1981). The biochemical composition and energy content of arctic marine macrozooplankton. Arctic 34 (4): 307-313

Platt, T., Brawn, V M., Irwin, B. (1969). Caloric and carbon equivalents of zooplankton biomass. J. Fish. Res. Bd Can. 26: $2345-2349$

Prus, T. (1970). Caloric values as an element of bioenergetical investigations. Polskie Arch. Hydrobiol. 17: 183-199

Slobodkin, L. B., Richman, S. (1961). Calories/gm in species of animals. Nature, Lond. 191. 299

Steimle, F. W. Terranova, R. J. (1985). Energy equivalents of marine organisms from the continental shelf of the temperate northwest Atlantic. J. Northw. Atl. Fish. Sci. 6: 117-124

Thayer, G. W. Schaaf, W. E., Angelovic, J. W., LaCroix, M. W (1973). Caloric measurements of some estuarine organisms. Fish. Bull. U.S. 71 (1): 289-296

Tyler, A. V (1973). Caloric values of some North Atlantic invertebrates. Mar. Biol. 19: 258-261 